\title{
A Novel Method for Extraction of Oils from Oleaginous Seeds
}

\author{
Abdelouaheb Djilani*,a and Amadou Dicko ${ }^{b}$ \\ ${ }^{a}$ LSBO, Badji Mokhtar University, B.P. 12, Annaba, Algeria \\ ${ }^{b}$ Chemistry Laboratory and Methodology for the Environment, Paul-Verlaine University, Metz, 1, \\ Boulevard Arago. Technopole 2000, 57078 Metz, France
}

\begin{abstract}
Um novo método de extração de óleos de sementes oleaginosas foi desenvolvido. Este método está baseado no uso de solução aquosa de monolaurato de polioxietilenoglicol sorbitano (Tween 20). Comparado com métodos existentes, a nova técnica é rápida e ambientalmente amigável. Em adição, o óleo obtido por este método tem as mesmas propriedades físico-químicas e composição similar àquelas obtidas pelo método clássico com um melhor potencial antioxidante, revelado pelo teste DPPH.
\end{abstract}

A new method of extraction of oils from oleaginous seeds was developed. This method is based on the use of aqueous solution of polyethylene glycol sorbitan monolaurate (Tween 20). Compared with existing methods, the new technique is rapid and environmentally friendly. In addition, the obtained oil by this method has the same physicochemical properties and similar composition as those obtained by the classical method with a better antioxidant potential revealed by DPPH test.

Keywords: oilseeds, extraction, Tween 20, cloud point

\section{Introduction}

Lipids have been constituents of human nutrition from ancient times and their correlation with health is well established, in addition the importance of oilseeds in global economy is indisputable..$^{1-3}$ Then the method of their extraction is of a great interest and different methods such as conventional methods, ${ }^{4}$ enzymatic extraction, ${ }^{5}$ ultrasound assisted extraction, ${ }^{6}$ microwaves assisted extraction, ${ }^{7}$ supercritical solvents extraction ${ }^{8}$ or other methods. ${ }^{9}$ Each method has shortcomings and advantages. ${ }^{10}$

In this paper a new method is developed to extract oils from seeds. We propose here a clean method by using surfactants as extraction agent with wetting properties, dispersion, solubilisation and emulsification for circumventing the solvents and reducing time. The selected seeds for this study are those of Nigella sativa. Therefore, the aim of this study was to test this hypothesis by determining the influence of surfactant concentration and treatment time (heating and stirring) on the efficiency of oil extraction from Nigella sativa seeds. The oils extracted by conventional method (extraction with hexane) and proposed

*e-mail: jilaniouaheb@yahoo.fr method (extraction with surfactant) were analyzed and characterized by using classical analytical procedures, spectroscopic and chromatographic methods.

\section{Experimental}

\section{Samples and reagents}

The seeds of Nigella sativa were purchased from local market and were carefully cleaned by hand to remove foreign materials. The cleaned seeds were dried for $18 \mathrm{~h}$ at $105{ }^{\circ} \mathrm{C}$ in an oven, and then ground with a coffee grinder and passed through a standard sieve of $0.5 \mathrm{~mm}$ and the fine powder obtained was stored at $-20^{\circ} \mathrm{C}$ until use. All experiments were performed with the same dried material. All the chemicals used were of analytical grade and were purchased from Sigma and Roth (Strasbourg, France).

\section{Conventional extraction (CE)}

Soxhlet extraction was employed to determine the oil yield for comparison with the technique proposed. With this aim, three extractions were carried out using for each $150 \mathrm{~mL}$ of $\mathrm{n}$-hexane and $10 \mathrm{~g}$ of the milled seeds. After 
extraction for overnight, the solution was filtered and then followed by solvent removal in a rotary evaporator under reduced pressure at $40{ }^{\circ} \mathrm{C}$. The oils obtained were then dried in the oven at $70 \pm 1^{\circ} \mathrm{C}$ for $2 \mathrm{~h}$, after which they were cooled in desiccators before weighed and the yields were calculated. The oil sample was kept at $4{ }^{\circ} \mathrm{C}$ in a refrigerator for further analysis.

\section{Surfactant assisted extraction (SAE)}

A $10 \mathrm{~g}$ sample was mixed in glass beaker with a surfactant aqueous solution to the required powder to solution ratio at different concentrations and the suspension was stirred (1000 rpm) and heated for a desired time at constant temperature. After which the mixture was acidified to $\mathrm{pH} 4-5$ with sulfuric acid $(1 \% \mathrm{~m} / \mathrm{v})$ and $3 \mathrm{~g}$ of ammonium sulphate was added to precipitate proteins. Then the content was boiled for $5 \mathrm{~min}$ to reach cloud point of Tween $20\left(76{ }^{\circ} \mathrm{C}\right)$. The sample was left for $30 \mathrm{~min}$ to cool at room temperature, two phases are formed and the upper oil phase was collected after centrifugation at $2000 \times \mathrm{g}$ for $10 \mathrm{~min}$, weighed and stored at $4{ }^{\circ} \mathrm{C}$. In all cases, control experiments were performed without surfactant addition and all experiments were performed in triplicates.

\section{Physicochemical analysis of the oil components}

Acid, saponification, iodine and peroxide values of the sample oils were determined, according to AOCS. ${ }^{1}$ These properties determined for extracted oil obtained at the optimal operating conditions and the oil extracted by conventional method.

\section{Gas chromatographic analysis}

Fatty acid compositions of the oils extracted by $\mathrm{CE}$ and SAE were determined using gas chromatography (GC) after derivatization to fatty acid methyl esters (FAME). The preparation of FAME was performed via transesterification. Then one milliliter of the test sample was thoroughly mixed with $1 \mathrm{~mL}$ of a $10 \%$ (v/v) solution of concentrated $\mathrm{H}_{2} \mathrm{SO}_{4}$ in methanol, the mixture was shaken vigorously and then heated at $110{ }^{\circ} \mathrm{C}$ for $2 \mathrm{~h}$ in closed vials. After cooling, the upper phase was separated.

Methyl esters were analyzed by Perkin-Elmer Gas Chromatography interfaced to Clarus 500 mass spectrometer equipped with a hydrogen flame ionization detector. Separation was performed on fused silica capillary column $(30 \mathrm{~m} \times 0.32 \mathrm{~mm} \times 0.25 \mu \mathrm{m}) \mathrm{HP} 5-\mathrm{MS}$ (crossbond $5 \%$ biphenyl, 95\% dimethylpolysiloxane). The carrier gas was helium with a flow rate of $1 \mathrm{~mL} \mathrm{~min}^{-1}$; split ratio was 1:100. The column temperature was programmed as follow: the initial column temperature was $50^{\circ} \mathrm{C}$, which was maintained for $1 \mathrm{~min}$, from 50 to $180^{\circ} \mathrm{C}$ at $25^{\circ} \mathrm{C} \mathrm{min}^{-1}$, from 180 to $260{ }^{\circ} \mathrm{C}$ at $5{ }^{\circ} \mathrm{C} \mathrm{min}{ }^{-1}$ and the detector and injector temperature held constant at $250{ }^{\circ} \mathrm{C}$.

Identification of fatty acid methyl esters was carried out by comparison of retention times of unknown peaks with authentic fatty acid methyl esters. Fatty acid methyl esters were quantified as percentages of the total methyl ester peak areas.

\section{Antioxidant activity}

The oil samples obtained under optimal conditions of new method and that obtained with conventional method were subjected to analysis of their antioxidant activity using a 2,2-diphenyl-1-picrylhydrazyl (DPPH) radical-scavenging assay as described by Zhang et al. ${ }^{11}$ with a slight modification. An aliquot of oil $(100 \mu \mathrm{L})$ was mixed with $1.4 \mathrm{~mL}$ of toluene and then added to $1 \mathrm{~mL}$ of $0.004 \%$ $\mathrm{DPPH}$ in toluene. The mixture was shaken vigorously and was stayed in dark for $30 \mathrm{~min}$ at room temperature. The absorbance data were read at $515 \mathrm{~nm}$ using a Varian spectrophotometer.

The radical-scavenging activities of the samples, expressed as percentage inhibition of DPPH, were calculated according to equation 1 :

$\mathrm{I}(\%)=100 \frac{\mathrm{A}_{\text {blank }}-\mathrm{A}_{\text {sample }}}{\mathrm{A}_{\text {blank }}}$

where, $\mathrm{A}_{\text {blank }}$ is the absorbance of the control reaction mixture excluding the oil extract and $\mathrm{A}_{\text {sample }}$ is the absorbance of the tested oil extract solution.

The amount of sample needed to decrease the initial DPPH concentration by $50 \%\left(\mathrm{IC}_{50}\right)$ was calculated graphically by using the curve drawn for inhibition percentage versus used concentration.

\section{Results and Discussion}

\section{Effect of surfactant concentration}

Effect of surfactant concentration on yield of extraction is shown in Figure 1. When the concentration of the solution is increased the amount of extracted oil increased gradually. Although, higher concentration values showed extraction difficulties due to formation of intermediary layer between oil and aqueous phase. Therefore concentration of $0.5 \%$ was selected as the most suitable concentration for extraction. 


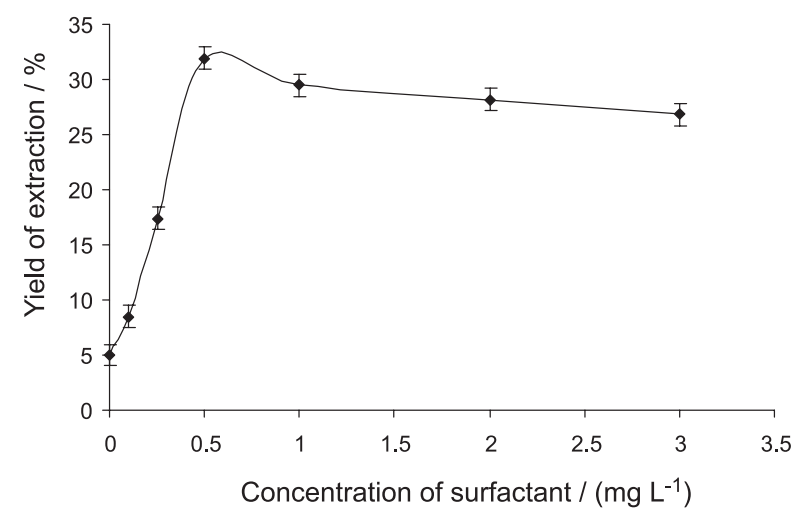

Figure 1. Effect of surfactant concentration on yield extraction.

\section{Effect of extraction time}

Figure 2 shows the effect of time on the yield of oil. The results demonstrated that the yield of oil increases with the extraction time and attains a plateau at $2 \mathrm{~h}$. In any case, based on the results so far, 60 min was found to be an optimum operating time for SAE.

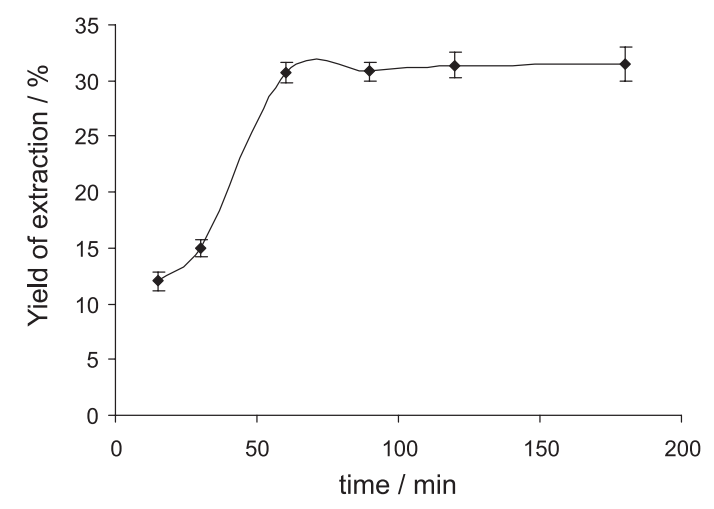

Figure 2. Variation of yield extraction with time treatment.

\section{Effect of temperature}

As shown in Figure 3, the yield of oil changes with increasing temperature. When the temperature changed from 30 to $65^{\circ} \mathrm{C}$, the yield of oil increased about $28 \%$ and

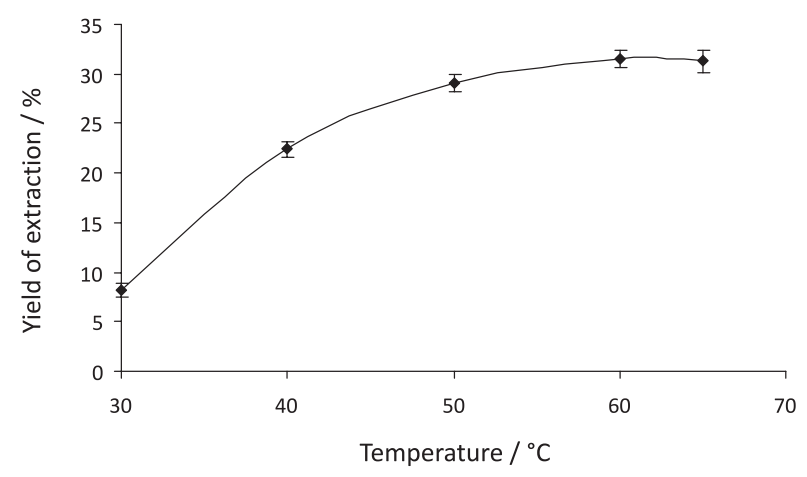

Figure 3. Effect of temperature on yield extraction. it is possible to observe that $60{ }^{\circ} \mathrm{C}$ is the optimum temperature.

\section{Effect of liquid to solid ratio}

As shown in Figure 4, the yields of oil extracted by SAE was found to be dependent with the ratio of liquid to solid and then the best yield was obtained with the ratio 1:20.

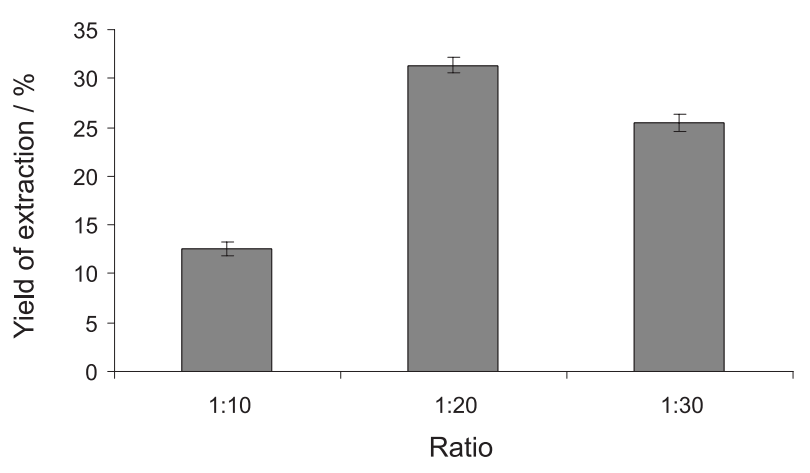

Figure 4. Solid to liquid ratio $\left(\mathrm{g} \mathrm{mL}^{-1}\right)$.

\section{Oil characterization}

\section{Physicochemical properties}

Oils obtained by both methods are characterized and the results are summarized in Table 1.

Table 1. Physicochemical properties of sample oils

\begin{tabular}{|c|c|c|}
\hline Physicochemical properties & $\mathrm{CE}$ & SAE \\
\hline Acid index (mg of $\mathrm{KOH} \mathrm{g} \mathrm{g}^{-1}$ of oil) & $24.1 \pm 0.5$ & $21.5 \pm 0.4$ \\
\hline Saponification index (mg of $\mathrm{KOH} \mathrm{g} \mathrm{g}^{-1}$ of oil) & $199 \pm 5$ & $189 \pm 4$ \\
\hline Iodine value ( $\mathrm{g}$ of $\mathrm{I}_{2} 100 \mathrm{~g}^{-1}$ of oil) & $111 \pm 2$ & $117 \pm 3$ \\
\hline Peroxide value (mequiv. $\mathrm{O}_{2} \mathrm{~kg}^{-1}$ of oil) & $9.6 \pm 0.3$ & $8.1 \pm 0.2$ \\
\hline
\end{tabular}

Values are given as means of three replicates \pm SD.

\section{Gas chromatography analysis}

The fatty acids profile of Nigella seed oils obtained by CE and SAE methods is shown in Table 2.

\section{Antioxidant activity}

$\mathrm{IC}_{50}$ in this test was defined as the concentration of the oil required to cause $50 \%$ inhibition of the total DPPH radicals. $\mathrm{IC}_{50}$ of the sample was expressed in $\mathrm{mg} \mathrm{mL}^{-1}$ and calculated through the interpolation of linear regression analysis. A lower value corresponds to a higher antioxidant activity of the oil sample.

Inhibition potentials of both samples through DPPH scavenging activity are presented in Figure 5. $\mathrm{IC}_{50}$ values for oils obtained by SAE and CE method are 28.85 and $42.07 \mathrm{mg} \mathrm{mL}^{-1}$, respectively. 
Table 2. Fatty acid composition of Nigella sativa seed oils obtained by both methods

\begin{tabular}{lcc}
\hline Fatty acid & \multicolumn{2}{c}{ Percent of total fatty acids } \\
\cline { 2 - 3 } Myristic & CE & SAE \\
Palmitic & $0.23 \pm 0.08$ & $0.25 \pm 0.02$ \\
Stearic & $17.8 \pm 0.15$ & $17.1 \pm 0.26$ \\
Oleic & $2.86 \pm 0.11$ & $2.68 \pm 0.14$ \\
Linoleic & $22.45 \pm 0.33$ & $22.91 \pm 0.39$ \\
Linolenic & $53.23 \pm 0.54$ & $53.49 \pm 0.39$ \\
Arachidic & $0.68 \pm 0.09$ & $0.73 \pm 0.07$ \\
Eicosenoic & $0.12 \pm 0.05$ & $0.14 \pm 0.04$ \\
Behenic & $0.39 \pm 0.09$ & $0.42 \pm 0.06$ \\
\hline
\end{tabular}

Values are given as means of three replicates \pm SD.

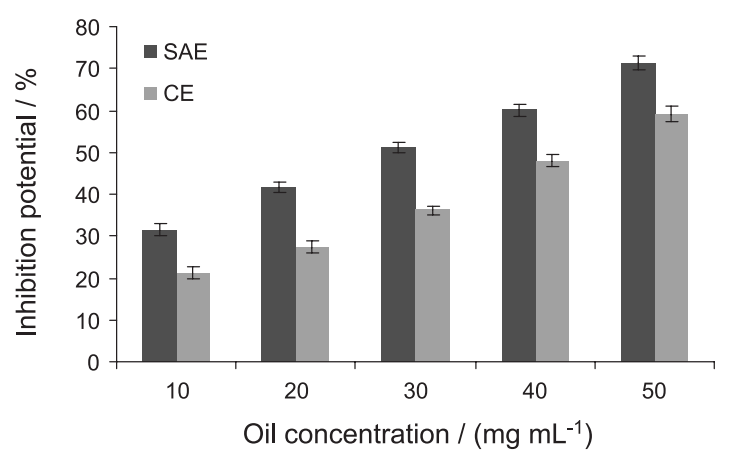

Figure 5. Antioxidant activity of oils obtained by CE and SAE methods.

\section{Conclusion}

Varying several parameters, such as concentration, temperature, time and ratio of solid to liquid, an oil with similar quality ${ }^{12}$ was obtained and sometimes superior than that obtained by conventional method. The only drawback of the method is that the yield is still below of the method using solvents (31\% for SAE and 35\% for CE). Therefore, the use of surfactants confirm the results previously obtained of extraction with alkaloids. ${ }^{13}$ The results obtained with the use of surfactant, corroborate that the method allows an extraction with high quality and good yield, less pollution and a significant economic and safety benefits.

\section{Acknowledgment}

Dr. A. Djilani would like to thank the Agence Universitaire de Francophonie (AUF) for the financial support.

\section{References}

1. Bockisch, M.; Fats and Oils Handbook; AOCS Press, Champaign: Illinois, 1998.

2. Mozaffarian, D.; Clarke, R.; Eur. J. Clin. Nutr. 2009, 63, S22.

3. Dupont, J.; White, P. J.; Carpenter, M. P.; Schaefer, E. J.; Meydani, S. N.; Elson, C. E.; Woods, M.; Gorbach, S. L.; J. Am. Coll. Nutr. 1990, 9, 438.

4. Pradhan, R. C.; Meda, V.; Rout, P. K.; Naik, S.; Dalai, A. K.; J. Food Eng. 2010, 98, 393.

5. Rosenthal, A.; Pyle, D. L.; Niranjan, K.; Enzyme Microb. Technol. 1996, 19, 402.

6. Luque-Garcia, J. L.; Luque de Castro, M. D.; J. Chromatogr., A 2004, 1034, 237.

7. Terigar, B. G.; Balasubramanian, S.; Boldor, D.; Bioresour. Technol. 2010, 101, 6510.

8. Kim, H. J.; Lee, S. B.; Park, K. A.; Hong, I. K.; Sep. Purif. Technol. 1999, 15, 1.

9. Wang, L.; Weller, C. L.; Trends Food Sci. Technol. 2006, 17, 300.

10. Passos, C. P.; Silva, R. M.; Silva, F. A.; Coimbra, M. A.; Silva, C. M.; Chem. Eng. J. 2010, 160, 634.

11. Zhang, S.; Zu, Y. G.; Fu, Y. J.; Luo, M.; Liu, W.; Li, J.; Efferth, T.; Bioresour. Technol. 2010, 101, 2537.

12. Atta, M. B.; Food Chem. 2003, 83, 63.

13. Djilani, A.; Legseir, B.; Dicko, A.; Soulimani, R.; Younos, C.; J. Braz. Chem. Soc. 2006, 17, 518.

Submitted: April 5, 2011

Published online: August 9, 2011 